\title{
Increasing springtime ozone mixing ratios in the free troposphere over western North America
}

\author{
O. R. Cooper ${ }^{1,2}$, D. D. Parrish ${ }^{2}$, A. Stohl ${ }^{3}$, M. Trainer ${ }^{2}$, P. Nédélec ${ }^{4}$, V. Thouret ${ }^{4}$, J. P. Cammas ${ }^{4}$, S. J. Oltmans ${ }^{2}$, \\ B. J. Johnson ${ }^{2}$, D. Tarasick ${ }^{5}$, T. Leblanc ${ }^{6}$, I. S. McDermid ${ }^{6}$, D. Jaffe ${ }^{7}$, R. Gao ${ }^{2}$, J. Stith ${ }^{8}$, T. Ryerson ${ }^{2}$, K. Aikin ${ }^{1,2}$, \\ T. Campos $^{9}$, A. Weinheimer ${ }^{9} \&$ M. A. Avery ${ }^{10}$
}

In the lowermost layer of the atmosphere-the troposphereozone is an important source of the hydroxyl radical, an oxidant that breaks down most pollutants and some greenhouse gases ${ }^{1}$. High concentrations of tropospheric ozone are toxic, however, and have a detrimental effect on human health and ecosystem productivity ${ }^{1}$. Moreover, tropospheric ozone itself acts as an effective greenhouse gas ${ }^{2}$. Much of the present tropospheric ozone burden is a consequence of anthropogenic emissions of ozone precursors $^{3}$ resulting in widespread increases in ozone concentrations since the late $1800 \mathrm{~s}^{3-7}$. At present, east Asia has the fastestgrowing ozone precursor emissions ${ }^{8}$. Much of the springtime east Asian pollution is exported eastwards towards western North America ${ }^{9}$. Despite evidence that the exported Asian pollution produces ozone ${ }^{10}$, no previous study has found a significant increase in free tropospheric ozone concentrations above the western USA since measurements began in the late $1970 \mathrm{~s}^{5,11,12}$. Here we compile springtime ozone measurements from many different platforms across western North America. We show a strong increase in springtime ozone mixing ratios during 1995-2008 and we have some additional evidence that a similar rate of increase in ozone mixing ratio has occurred since 1984 . We find that the rate of increase in ozone mixing ratio is greatest when measurements are more heavily influenced by direct transport from Asia. Our result agrees with previous modelling studies, which indicate that global ozone concentrations should be increasing during the early part of the twenty-first century as a result of increasing precursor emissions, especially at northern mid-latitudes ${ }^{13}$, with western North America being particularly sensitive to rising Asian emissions ${ }^{14}$. We suggest that the observed increase in springtime background ozone mixing ratio may hinder the USA's compliance with its ozone air quality standard.

Inventoried global anthropogenic ozone precursor emissions of nitrogen oxides $\left(\mathrm{NO}+\mathrm{NO}_{2}=\mathrm{NO}_{x}\right)$ and volatile organic compounds increased rapidly during 1960-1990, but levelled off in the $1990 \mathrm{~s}^{15}$. Comprehensive inventories of ozone precursors have not yet been compiled for the years since 2000 and uncertainties remain whether total global emissions have increased since then. However, satellite measurements of column $\mathrm{NO}_{2}$ indicate increased $\mathrm{NO}_{x}$ emissions during 1996-2005 in China (up to 29\% per year) and other locations in Asia, while emissions decreased in Europe and the USA ${ }^{8}$. The most recent bottom-up inventories indicate that south and east
Asia's $\mathrm{NO}_{x}$ emissions increased 44\% during 2001-2006, with an increase of $55 \%$ within China ${ }^{16}$, while ozone precursor emissions decreased by more than a third across Europe ${ }^{1}(1990-2005)$ and the USA ${ }^{17}$ (1985-2008).

It is possible that increasing emissions from emerging economies like China, with relatively limited emissions controls, are outpacing reductions in the developed economies. This scenario would probably increase tropospheric ozone, which should be observable in the midtroposphere above western North America. This region is downwind of Asian emissions and also receives aged emissions from Europe and North America that have circled the northern hemisphere.

At the surface significant daytime ozone increases (0.19-0.50 parts per billion by volume per year, p.p.b.v. $\mathrm{yr}^{-1}$ ) have occurred at several rural sites in the western USA based on 1987-2004 yearly data ${ }^{11}$, while springtime ozone increased by $0.33-0.59$ p.p.b.v. $\mathrm{yr}^{-1}$. However, the causes of the ozone increases at these sites were not clearly identified. Merged ozone records from several US west coast sites show that springtime ozone increased by 0.46 p.p.b.v. $\mathrm{yr}^{-1}$ (1985-2007) when winds from the North Pacific Ocean were strongest, indicating an increase in marine boundary layer background ozone ${ }^{18}$. These rates are much higher than the surface ozone rate of increase (Northern Hemisphere annual average) attributed by chemical transport models to rising Asian emissions ${ }^{19}$.

Regarding the free troposphere above the western USA, no previous study had found a significant ozone increase, despite frequent impact by Asian pollution plumes 9 . Ozone measurements in the western North American free troposphere are relatively few, with the longest records being the weekly ozonesonde profiles above Edmonton, Alberta; Boulder, Colorado; and Trinidad Head, California. No significant ozone trend occurred above Edmonton during 1980-2001, but ozone did increase significantly during $1991-2001^{20}$. No significant increase was found above Boulder $(1985-2004)^{5}$ or Trinidad Head (1997-2007) ${ }^{21}$. Upper tropospheric ozone measurements made by commercial aircraft in the late 1970s and late 1990s revealed significant increases above the eastern USA, among other regions, but not above western North America where small sample sizes in the late 1990s may have prevented the identification of significant changes ${ }^{12}$. In contrast, mid-tropospheric ozone measurements made by research aircraft above coastal California during the springtime of 1984 and 2002 show an increase of 15 p.p.b.v. However, this apparent increase may simply have been due to interannual variability ${ }^{22}$.

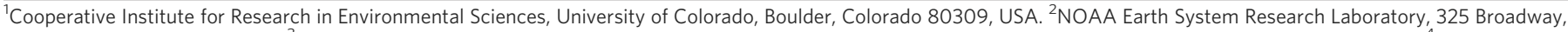

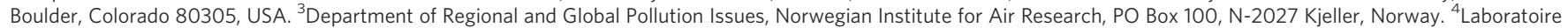
d'Aérologie, Centre National de la Recherche Scientifique, Observatoire Midi-Pyrénées, 14 Avenue E. Belin, 31400 Toulouse, France. ${ }^{5}$ Experimental Studies Research Division,

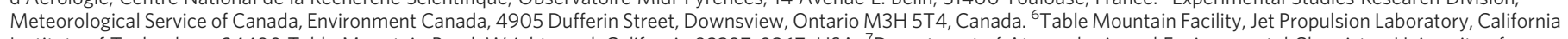
Institute of Technology, 24490 Table Mountain Road, Wrightwood, California 92397-0367, USA. ${ }^{7}$ Department of Atmospheric and Environmental Chemistry, University of

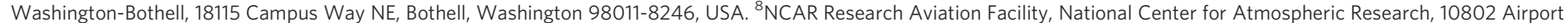

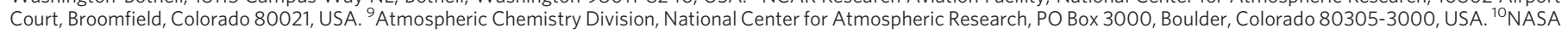
Langley Research Center, Hampton, Virginia 23681-2199, USA.
} 
Our goal is a reanalysis of all available free tropospheric ozone measurements above western North America during springtime of 1984-2008 to quantify the change in ozone using the largest data set possible. The analysis was restricted to April-May, when Asian emissions have their greatest impact on western North America ${ }^{9}$. Emphasis was placed on the mid-troposphere $(3.0-8.0 \mathrm{~km})$ where the most data are available, but the upper troposphere $(8.0-12.0 \mathrm{~km})$ was also addressed. Ozone measurements were gathered from ozonesondes, lidar and commercial and research aircraft across western North America $\left(25^{\circ}-55^{\circ} \mathrm{N}\right.$, $\left.130^{\circ}-90^{\circ} \mathrm{W}\right)$. A particle dispersion model (PDM) was used to determine the 15-day transport history of every measurement (see Methods).

Continuous ozone data with adequate sample sizes (see Methods) are available in the mid-troposphere during 1995-2008 (Fig. 1a), where median ozone values have a significant rate of increase of $0.63 \pm 0.34$ p.p.b.v. $\mathrm{yr}^{-1}$. Similar values are found for the $33 \mathrm{rd}$ and 67 th percentiles, whereas rates for the 95 th and 5 th percentiles are not significant. The only other year with a large sample size is 1984 , with a median ozone value (46 p.p.b.v.) that is 9-20 p.p.b.v. less than any year in the period 1995-2008. When 1984 is included in the analysis, the ozone rate of increase is slightly greater for all percentiles (Fig. 1a), suggesting that the 1995-2008 ozone rate of increase can be extended to 1984 . Transport patterns do vary interannually, but PDM analysis shows that no transport anomaly occurred in 1984, indicating that mid-tropospheric ozone was substantially lower in 1984 owing to reduced photochemical production rather than unusual transport. No other large April-May data sets are available from the 1980s to corroborate the 1984 measurements. However, mid-tropospheric ozone data measured above the western USA by a research aircraft in June $1985^{23}$ and May-June $1986^{24}$ have mean values of 47 and 53 p.p.b.v., respectively. Although these measurements occur later in the year, and have not undergone the same data averaging and processing as applied to the data in Fig. 1a, their low values are consistent with the 1984-2008 rate of increase found here.

Figure $1 \mathrm{~b}-\mathrm{g}$ shows the average transport history of air parcels in both the atmospheric column and the 300 m layer adjacent to the Earth's surface, associated with the lowest, middle and highest third of ozone measurements. The lowest ozone values have source regions to the west, stretching from the mid-latitudes to the tropics, with surface source regions mainly in the sub-tropical North Pacific. As ozone increases the source region shifts further west with greater influence from east Asia. Influence from the westernmost North Pacific is notable because it contains one of the world's major shipping routes, with global shipping producing about $13 \%$ of anthropogenic $\mathrm{NO}_{x}$ emissions ${ }^{15}$.

The analysis so far contains ozone measurements that experienced varying degrees of transport from the North American boundary layer. To focus on the background air entering western North America, measurements with a strong and recent influence ( $<5$ days) from the North American boundary layer were identified by the PDM and removed (Supplementary Information). This procedure resulted in a median ozone rate of increase of $0.71 \pm 0.45$ p.p.b.v. $\mathrm{yr}^{-1}$ for 1995-2008 (compared to $0.63 \pm 0.34$ p.p.b.v. $\mathrm{yr}^{-1}$ for the unfiltered data), and $0.76 \pm 0.29$ p.p.b.v. $\mathrm{yr}^{-1}$ for 1984-2008 (compared to $0.70 \pm 0.22$ p.p.b.v. $\mathrm{yr}^{-1}$ for the unfiltered data). The stronger rate of increase found in the background air demonstrates that recent North American influence is not responsible for the increasing ozone. Given the decreasing North American ozone precursor emissions since $1985^{8,14,17}$, and the decrease in urban extreme ozone events across much of the USA ${ }^{25}$, it is unlikely that aged North American emissions are contributing to the increase of background ozone. PDM output can also be used to identify trends in the frequency of transport from the important ozone precursor emission region of south Asia and east Asia (referred to as SA/EA and including India, southeast Asia and China). Although the quantity of air transported from the SA/EA boundary layer to the North American free troposphere varied interannually, we found no significant trend during 1995-2008.

To remove the influence of interannual variability associated with transport from various emission regions we examined the ozone rate of increase by dividing the full 1995-2008 ozone data set (Fig. 1a) according to weaker or stronger transport from a particular emission region. Figure 2 shows the residence time of the air parcels associated with weaker or stronger transport from the anthropogenic $\mathrm{NO}_{x}$ sources within SA/ EA. Ozone data with weaker transport from SA/EA have a strong association with transport from the central North Pacific and increase by $0.45 \pm 0.32$ p.p.b.v. $\mathrm{yr}^{-1}(P=0.01)$, which is less than the overall rate of $0.63 \pm 0.34$ p.p.b.v. $\mathrm{yr}^{-1}$ (Fig. 1a). In contrast, data with stronger transport from SA/EA have a strong surface influence from China and subtropical regions of the western North Pacific, with an additional influence from southeast Asia and northern India, and increase at a higher rate of $0.80 \pm 0.34$ p.p.b.v. $\mathrm{yr}^{-1}(P=0.00)$. Weaker or stronger transport from China alone yields similar results of $0.42 \pm 0.39$ p.p.b.v. $\mathrm{yr}^{-1}(P=0.04)$ and $0.72 \pm 0.36$ p.p.b.v. $\mathrm{yr}^{-1}(P=0.00)$, respectively. Because the direct transport routes from India and southeastern Asia to western North America traverse China ${ }^{9}$, this analysis cannot quantify the relative contributions of China, India and southeast Asia to the ozone increase. SA/ EA was the only region in the Northern Hemisphere associated with an ozone rate of increase greater than the overall rate of 0.63 p.p.b.v. $\mathrm{yr}^{-1}$. For example, strong transport from Japan/Korea has an ozone rate of increase of $0.52 \pm 0.40$ p.p.b.v. $\mathrm{yr}^{-1}(P=0.02)$, much lower than when transport from SA/EA is strong. The strong transport pattern from Japan/Korea has relatively long surface residence times above the western North Pacific, and shorter residence times above continental Asia (Supplementary Information). This small shift in transport away from continental Asia has a large impact on the ozone rate of increase above western North America.

Because this study shows a stronger ozone rate of increase above North America when air masses originate in the rapidly growing emission regions of SA/EA, recent ozone changes in Asia deserve attention (Supplementary Information). The limited long-term observations within Asia ${ }^{26-28}$ show ozone increases of 0.58-1.2 p.p.b.v. $\mathrm{yr}^{-1}$ at surface sites in China, Japan and Taiwan, comparable to our rate of 0.80 p.p.b.v. $\mathrm{yr}^{-1}$ above North America when transport from Asia is strong. Recent model analysis indicates that about half of the ozone transported from Asia to North America is produced in Asia and the rest is produced during trans-Pacific transport ${ }^{29}$.

Lastly, the ozone rate of increase was calculated for the upper troposphere, using all available data during 1995-2008. Only the 50th and 33rd percentiles show significant increases in ozone- $-0.58 \pm 0.52$ and $0.66 \pm 0.52$, respectively - with values and transport history similar to the mid-tropospheric analysis. The strong influence of stratospheric intrusions in the upper troposphere probably explains the lack of significant rates of increase in the 67th and 95th percentiles. Further data analysis in the Supplementary Information shows that the mid- and upper tropospheric results are robust and not strongly influenced by air mass sampling biases, vertical ozone variation, or stratospheric impact.

We explored the discrepancy between this study, which shows a statistically significant ozone increase above western North America, and previous ozonesonde analyses which do not. Mid-tropospheric ozone rates of change above Trinidad Head (1998-2008), Boulder (1995-2008) and Edmonton (1995-2008), were 0.37 \pm 0.58 p.p.b.v. $\mathrm{yr}^{-1}$, $0.05 \pm 0.46$ p.p.b.v. $\mathrm{yr}^{-1}$, and $0.12 \pm 0.52$ p.p.b.v. $\mathrm{yr}^{-1}$, respectively. Although these values are positive, they are much lower than the rate in Fig. 1a and statistically insignificant. The annual sample sizes for the ozonesonde sites are fairly low (32-564 data points), with larger sample sizes occurring in more recent years at Edmonton and Trinidad Head. The lack of significant rates of increase from ozonesondes could be due to small sample sizes in a region of high springtime ozone variability, requiring a much longer data record to detect any significant increase $^{11,30}$. Removing the ozonesondes from the full data set has little impact on this study, slightly increasing the 1995-2008 midtropospheric ozone rate of change from $0.63 \pm 0.34$ p.p.b.v. $\mathrm{yr}^{-1}$ to $0.69 \pm 0.43$ p.p.b.v. $\mathrm{yr}^{-1}$.

This study has implications for North American air quality ${ }^{14,19}$ and quantification of the radiative forcing due to ozone ${ }^{2}$. Our data provide an important benchmark for model simulations of free 

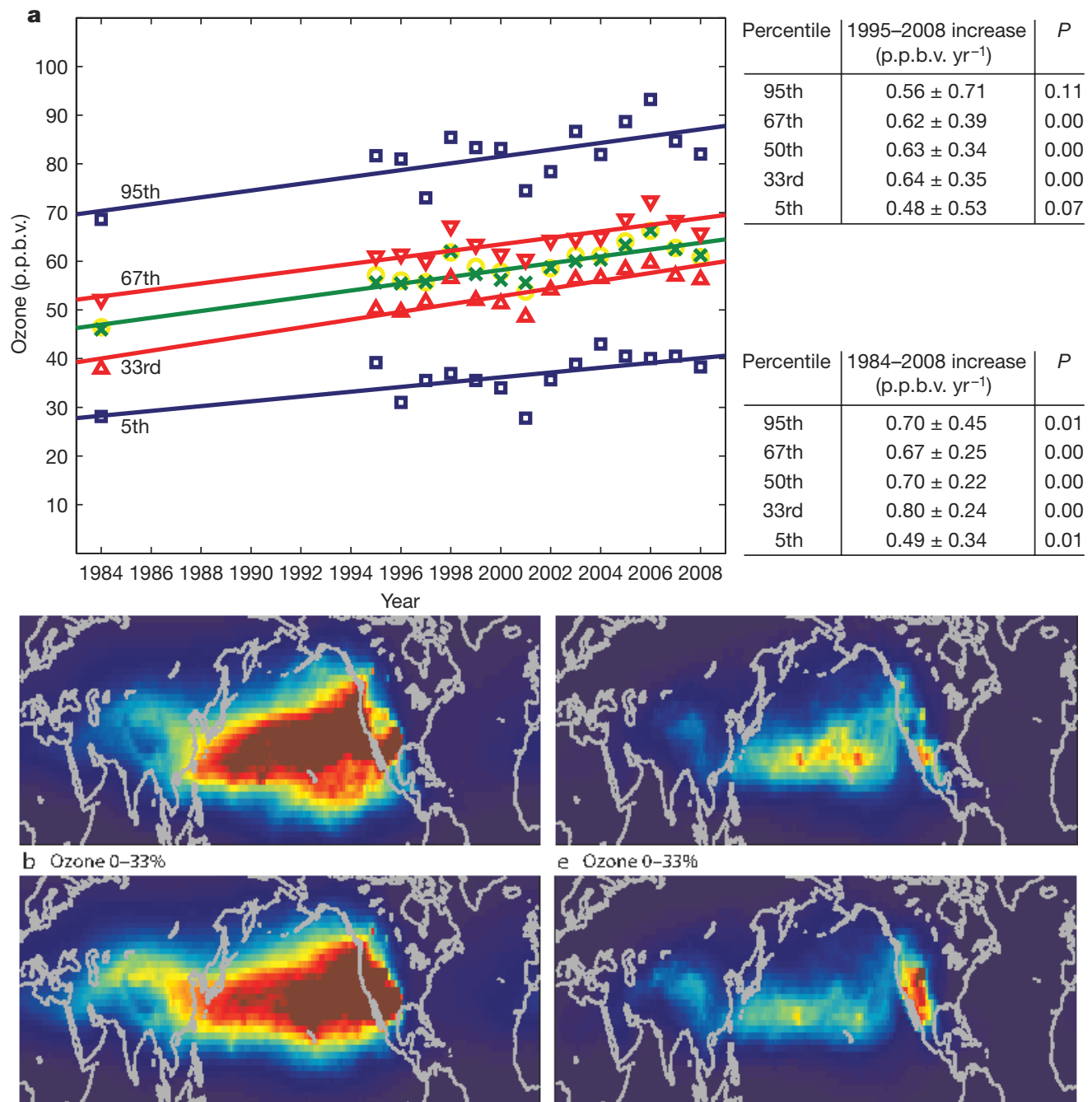

e Ozone $0-33 \%$

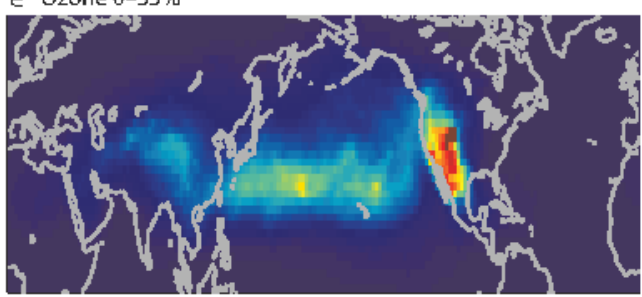

c Ozone 34-66\%

f Ozone 34-66\%

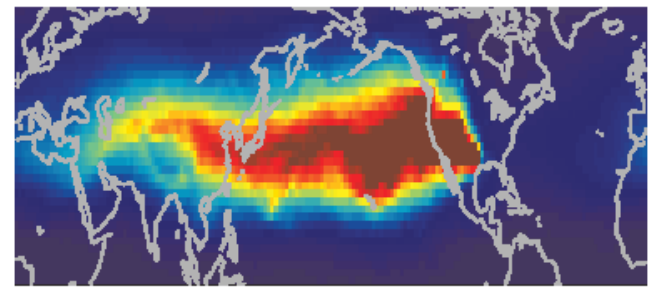

d Ozone 67-99\%

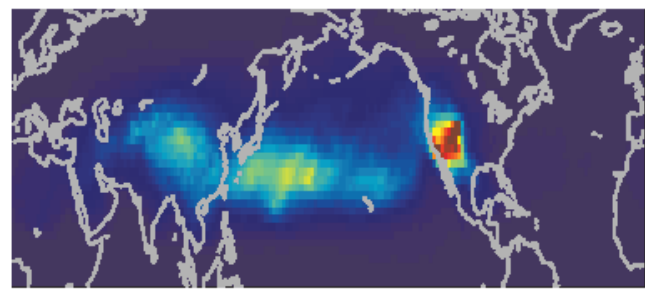

g Ozone $67-99 \%$
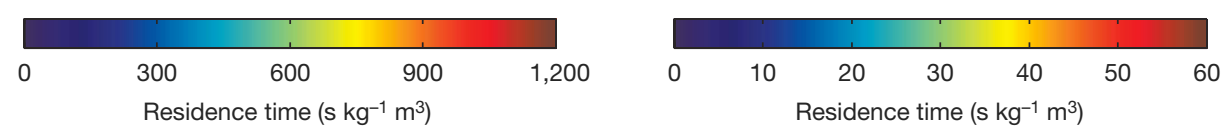

Figure 1 | Springtime ozone distributions for 1984, 1995-2008 in the midtroposphere (3.0-8.0 km), and air mass source regions. a, Distributions of springtime ozone measurements made in the troposphere between 3.0 and $8.0 \mathrm{~km}$ (stratospheric samples have been filtered out). The green line and data points are the median, and the yellow data points are means. The upper and lower blue lines (and data points) indicate the 95th and 5th percentiles. The upper and lower red lines (and data points) indicate the 67th and 33rd percentiles. Ozone sample sizes range from 1,663 in 1984 to 8,587 in 2006 (see the Supplementary Information). Also shown are the ozone rates of increase for 1984-2008 and 1995-2008, as determined from the slope of the linear regression. The range on the slope indicates the $95 \%$ confidence limit that the slope lies within that range. Ozone data were gathered over mid-latitude western

tropospheric ozone downwind of Asia. Models that can reproduce the observed ozone rate of increase in this region will provide more accurate estimates of changes in air quality and ozone radiative forcing since pre-industrial times.

North America $\left(25^{\circ}-55^{\circ} \mathrm{N}, 130^{\circ}-90^{\circ} \mathrm{W}\right)$, as shown in the Supplementary Information. The transport history of each ozone measurement was determined by calculating a retroplume with the FLEXPART PDM (see Methods and Supplementary Information). Every retroplume consisted of 40,000 back-trajectory particles released from the time and location of each measurement and advected backwards in time for 15 days. b-d, The average 1984-2008 retroplume for three ranges of ozone measurements, expressed as column residence times. $\mathbf{e - g}$, The corresponding retroplume residence times in the lowest $300 \mathrm{~m}$ of the atmosphere (the footprint layer). Ozone percentile ranges: $b$ and e, 0-33rd, $c$ and f, 34th-66th; d and g, 67th-99th. Column and footprint sample sizes are equal because every 15 -day retroplume has some degree of transport through the lowest $300 \mathrm{~m}$ of the atmosphere.

We suggest that the free tropospheric ozone increase could also affect the surface. Previous studies show that polluted midtropospheric air entering western North America can descend to the surface and modify the composition of the boundary layer (see 

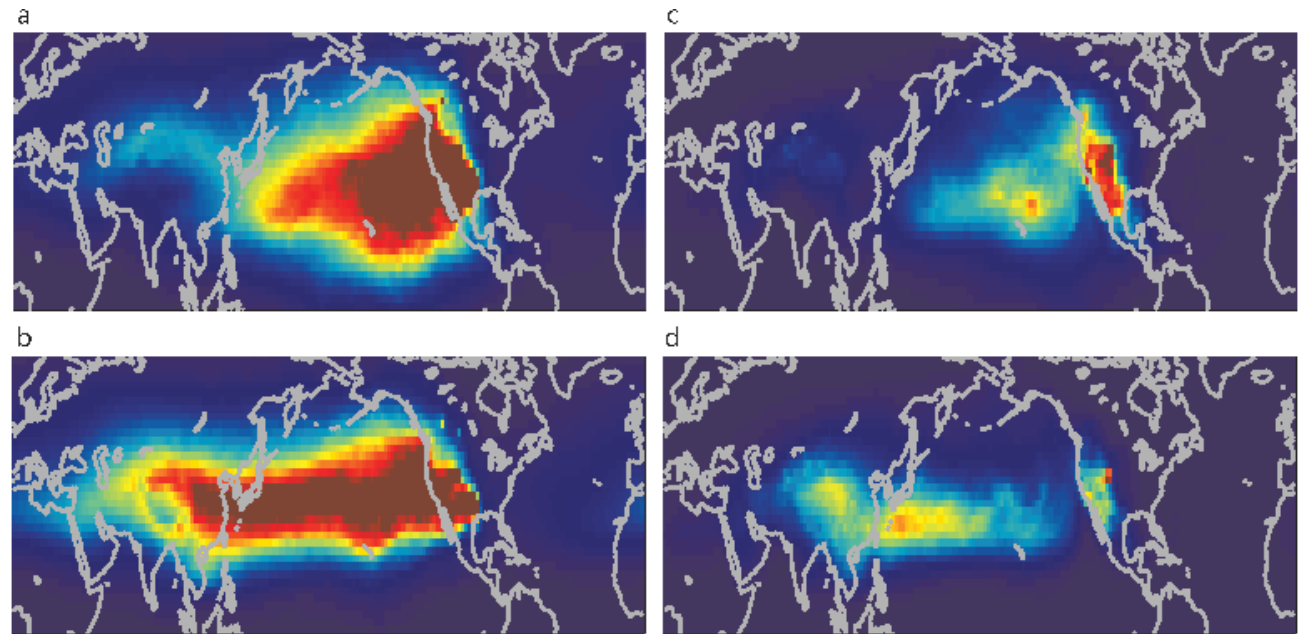

d
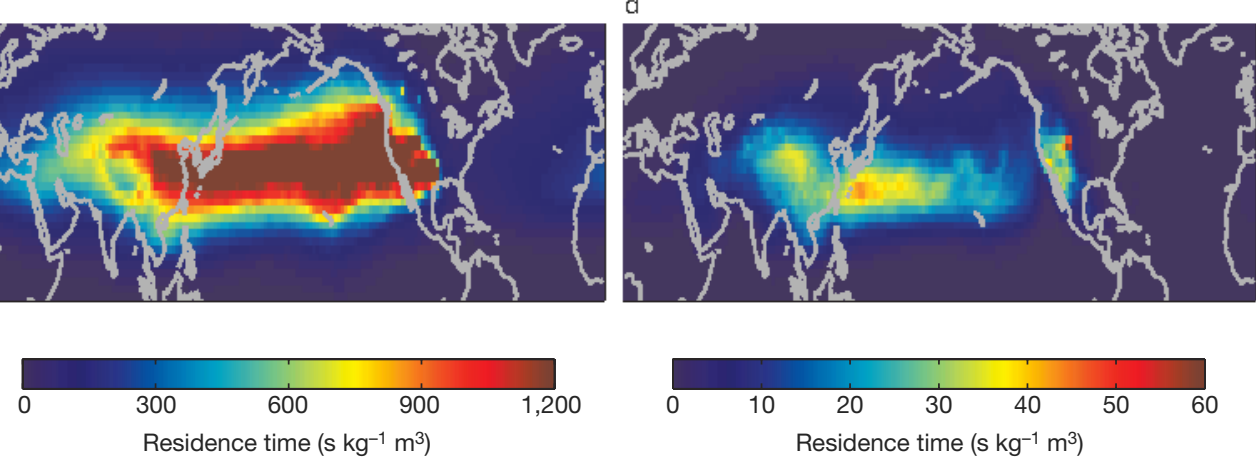

Figure 2 | Average 1995-2008 FLEXPART retroplume residence times. Average retroplume residence times in the atmospheric column (a and b) and footprint layer (c and d) for weaker (a and c) and stronger (b and d) transport from the SA/EA region. The retroplumes associated with every 1995-2008 ozone measurement in Fig. 1a were ranked according to the amount of time spent in the boundary layer above the SA/EA emissions

review in the Supplementary Information). Our results support earlier work that indicates that rising Asian ozone precursor emissions would cause springtime surface ozone to increase in western North America since the 1980s, despite decreasing domestic emissions ${ }^{14}$. Finally, summertime extreme ozone events in many US urban areas have decreased ${ }^{25}$, while some rural and marine sites in the western US show increasing ozone $\mathrm{e}^{11,18}$, possibly due to increasing background ozone. Future studies are required to quantify free tropospheric ozone trends above North America in other seasons.

\section{METHODS SUMMARY}

The ozone data were measured by: (1) electrochemical concentration cell ozonesondes, accuracy: $\pm 10 \%$; (2) an ozone lidar, accuracy: $\pm 5-25 \%$; (3) MOZAIC commercial aircraft, accuracy: \pm (2 p.p.b.v. $+2 \%)$; (4) a variety of research aircraft flights with instrument accuracies that are generally better than $\pm 5 \%$ or \pm 5 p.p.b.v.. The data were averaged over a $0.2^{\circ} \times 0.2^{\circ}$ grid, at $200 \mathrm{~m}$ vertical resolution and $1 \mathrm{~min}$ temporal resolution. All years have a sample size of at least 1,200 measurements, indicating that the median values are within $\pm 2 \%$ of the true ozone median value, at the $99 \%$ confidence level. The data have an approximately normal distribution and the straight-line fits through the ozone percentiles (Fig. 1a) are calculated using the least-squares method of simple linear regression. The slopes of these lines indicate the increase of ozone per year for 1984-2008. The $P$ value indicates the statistical significance of the linear relationship, determined by first calculating $R$, the correlation coefficient between ozone and time. We then test the null hypothesis that $R^{2}=0$ (no linear relationship) using the standard $F$-statistic (ratio of the mean square regression to the mean square residual). If the probability $P$ associated with the $F$ statistic is small ( $P \leq 0.05$ ), the null hypothesis is rejected with a confidence level $\geq 95 \%$.

The FLEXPART Lagrangian particle dispersion model produced the 15-day retroplumes for each ozone measurement with back-trajectory calculations based upon global ECMWF wind fields with a temporal resolution of $3 \mathrm{~h}$, horizontal resolution of $1^{\circ} \times 1^{\circ}$, and 60 (90) vertical levels in 1984-2005 (2006-2008). Back-trajectory particles are transported by the resolved winds, parameterized sub-grid motions, and a parameterized convection scheme. Further details on FLEXPART and the ozone data sets are given in the Supplementary Information.

1. The Royal Society. Ground-level Ozone in the 21st century: Future Trends, Impacts and Policy Implications Royal Society policy document 15/08, RS1276, 〈http://

regions. The $50 \%$ of retroplumes with the longest residence times were categorized as having stronger transport from SA/EA, while the rest were categorized as having weaker transport from SA/EA. For each group of retroplumes the average column and footprint was calculated (1995-2008), and for each group the ozone rate of change was also calculated (reported in the main text).

royalsociety.org/Report_WF.aspx?pageid=7924\&terms=ground-level+ozone (2008).

2. Intergovernmental Panel on Climate Change. Climate Change 2007-The Physical Science Basis, Contribution of Working Group I to the Fourth Assessment Report of the Intergovernmental Panel on Climate Change (Cambridge Univ. Press, 2007).

3. Horowitz, L. W. Past, present, and future concentrations of tropospheric ozone and aerosols: methodology, ozone evaluation, and sensitivity to aerosol wet removal. J. Geophys. Res. 111, D22211, doi:10.1029/2005JD006937 (2006).

4. Staehelin, J., Thudium, J., Buehler, R., Volz-Thomas, A. \& Graber, W. Trends in surface ozone concentrations at Arosa (Switzerland). Atmos. Environ. 28, 75-87 (1994).

5. Oltmans, S. J. et al. Long-term changes in tropospheric ozone. Atmos. Environ. 40, 3156-3173 (2006)

6. Thouret, $V$. et al. Tropopause referenced ozone climatology and inter-annual variability (1994-2003) from the MOZAIC programme. Atmos. Chem. Phys. 6, 1033-1051 (2006)

7. Zbinden, R. M. et al. Mid-latitude tropospheric ozone columns from the MOZAIC program: climatology and interannual variability. Atmos. Chem. Phys. 6, 1033-1051 (2006).

8. van $\operatorname{der} \mathrm{A}, \mathrm{R}$. J, et al. Trends, seasonal variability and dominant $\mathrm{NO}_{\mathrm{x}}$ source derived from a ten year record of $\mathrm{NO}_{2}$ measured from space. J. Geophys. Res. 113, D04302, doi:10.1029/2007JD009021 (2008)

9. Stohl, A., Eckhardt, S., Forster, C., James, P. \& Spichtinger, N. On the pathways and timescales of intercontinental air pollution transport. J. Geophys. Res. 107 (D23), 4684, doi:10.1029/2001JD001396 (2002).

10. Hudman, R. C. et al. Ozone production in transpacific Asian pollution plumes and implications for ozone air quality in California. J. Geophys. Res. 109, D23S10, doi:10.1029/2004JD004974 (2004)

11. Jaffe, D. \& Ray, J. Increase in surface ozone at rural sites in the western US. Atmos. Environ. 41, 5452-5463 (2007)

12. Schnadt Poberaj, $C$. et al. Long-term changes in UT/LS ozone between the late 1970s and the 1990s deduced from the GASP and MOZAIC aircraft programs and from ozonesondes. Atmos. Chem. Phys. 9, 5343-5369 (2009).

13. Stevenson, D. S. et al. Multimodel ensemble simulations of present-day and nearfuture tropospheric ozone. J. Geophys. Res. 111, D08301, doi:10.1029/ 2005JD006338 (2006).

14. Jacob, D. J., Logan, J. A. \& Murti, P. P. Effect of rising Asian emissions on surface ozone in the United States. Geophys. Res. Lett. 26, 2175-2178 (1999).

15. Schultz, M. \& Rast, S. (eds) RETRO Emission Data Sets and Methodologies for Estimating Emissions, Work Package 1, Deliverable D1-6 Report from REanalysis of the TROpospheric chemical composition over the past 40 years. 1-144 〈http:// retro.enes.org/pub_reports.shtml (2007).

16. Zhang, Q. et al. Asian emissions in 2006 for the NASA INTEX-B mission. Atmos. Chem. Phys. 9, 5131-5153 (2009).

17. US Environmental Protection Agency. National Emissions Inventory (NEI) Air Pollutant Emissions Trends Data 〈http://www.epa.gov/ttnchiel/trends/〉 (2009). 
18. Parrish, D. D., Millet, D. B. \& Goldstein, A. H. Increasing ozone in marine boundary layer inflow at the west coasts of North America and Europe. Atmos. Chem. Phys. 9, 1303-1323 (2009).

19. Fiore, A. M. et al. Multimodel estimates of intercontinental source-receptor relationships for ozone pollution. J. Geophys. Res. 114, D04301, doi:10.1029/ 2008JD010816 (2009).

20. Tarasick, D. W., Fioletov, V. E., Wardle, D. I., Kerr, J. B. \& Davies, J. Changes in the vertical distribution of ozone over Canada from ozonesondes: 1980-2001. J. Geophys. Res. 110, D02304, doi:10.1029/2004JD004643 (2005).

21. Oltmans, S. J., Lefohn, A. S., Harris, J. M. \& Shadwick, D. S. Background ozone levels of air entering the west coast of the US and assessment of longer-term changes. Atmos. Environ. 42, 6020-6038 (2008).

22. Parrish, D. D. et al. Changes in the photochemical environment of the temperate North Pacific troposphere in response to increased Asian emissions. J. Geophys. Res. 109, D23S18, doi:10.1029/2004JD004978 (2004).

23. Luke, W. T., Dickerson, R. R., Ryan, W. F., Pickering, K. E. \& Nunnermacker, L. J. Tropospheric chemistry over the lower Great Plains of the United States. 2: Trace gas profiles and distributions. J. Geophys. Res. 97, 20647-20670 (1992).

24. Luke, W. T. Reactive Nitrogen Compounds in the Troposphere: Observations, Transport, and Photochemistry PhD dissertation, Univ. Maryland (1990).

25. Lefohn, A. S., Shadwick, D. \& Oltmans, S. J. Characterizing long-term changes in surface ozone levels in the United States (1980-2005). Atmos. Environ. 42, 8252-8262 (2008)

26. Chou, C. C.-K., Liu, S. C., Lin, C.-Y., Shiu, C.-J. \& Chang, K.-H. The trend of surface ozone in Taipei, Taiwan, and its causes: implications for ozone control strategies. Atmos. Environ. 40, 3898-3908 (2006).

27. Ding, A. J., Wang, T., Thouret, V., Cammas, J.-P. \& Nédélec, P. Tropospheric ozone climatology over Beijing: analysis of aircraft data from the MOZAIC program. Atmos. Chem. Phys. 8, 1-13 (2008).

28. Tanimoto, $\mathrm{H}$. Increase in springtime tropospheric ozone at a mountainous site in Japan for the period 1998-2006. Atmos. Environ. 43, 1358-1363 (2009).

29. Zhang, L. et al. Transpacific transport of ozone pollution and the effect of recent Asian emission increases on air quality in North America: an integrated analysis using satellite, aircraft, ozonesonde, and surface observations. Atmos. Chem. Phys. 8, 6117-6136 (2008)

30. Logan, J. et al. Trends in the vertical distribution of ozone: a comparison of two analyses of ozonesonde data. J. Geophys. Res. 104, 26373-26399 (1999).

Supplementary Information is linked to the online version of the paper at www.nature.com/nature.

Acknowledgements This work was supported in part by NOAA's Climate Goal Program. We acknowledge the support of MOZAIC by the European Communities, EADS, Airbus and the airlines (Lufthansa, Austrian, Air France) who have carried MOZAIC equipment free of charge since 1994. B. Ridley, NCAR (retired), measured ozone from the NCAR C-130 during TOPSE.

G. L. Gregory, NASA (retired), measured ozone from the Convair CV-990 during CITE-1C. M. Proffitt, NOAA (retired) measured ozone from the NASA ER2 during STRAT and POLARIS, and measured ozone from the NASA WB57 during WAM. PACDEX ozone data were provided by NCAR/EOL under sponsorship of the National Science Foundation (http://data.eol.ucar.edu/) EDGAR (http://www.mnp.nl/edgar) is a product of the National Institute for Public Health and the Netherlands Organisation for Applied Scientific Research and is part of the Global Emissions Inventory Activity of IGBP/IGAC. Finally we thank R. Dickerson for providing the mean ozone values for June 1985 and May-June 1986.

Author Contributions O.R.C., D.D.P., A.S. and M.T conceived the study and guided its development. O.R.C. merged the ozone datasets and ran the PDM with assistance from A.S. O.R.C. analysed the data and wrote the text. P.N., V.T., J.P.C., S.J.O., B.J.J., D.T., T.L., I.S.M., D.J., R.G., J.S., T.R., K.A., T.C., A.W. and M.A.A. made the ozone measurements and guided interpretation of the datasets.

Author Information Reprints and permissions information is available at www.nature.com/reprints. The authors declare no competing financial interests. Correspondence and requests for materials should be addressed to O.R.C. (owen.r.cooper@noaa.gov). 